\title{
Pengaruh Kepemilikan Manajerial, Ukuran Perusahaan dan Kualitas Audit Terhadap Integritas Laporan Keuangan
}

\author{
Septian Dwi Santoso, Pipit Rosita Andarsari \\ Institut Teknologi dan Bisnis Asia Malang \\ Email1@septiandwi027@gmail.com, Email2@pipit.ra@asia.ac.id
}

*Corresponding Author

Diajukan : 25 Nopember 2021

Disetujui : : 15 Desember 2021

Dipublikasi : 6 Januari 2022

\begin{abstract}
The research has the objective to find out the existence of the managerial ownership, firm size and audit quality on the integrity of financial statements. The population in this study is a food and beverage sub-sector manufacturing company listed on the Indonesia Stock Exchange in 2017-2020 which is used using a purposive sampling technique. The sample in this study were 16 companies. The types of research data are quantitative data and secondary data sources. The data analysis technique used descriptive statistical analysis, logistic regression analysis and t test. The results of the research on managerial ownership, firm size and audit quality have no effect on the integrity of financial statements.
\end{abstract}

Key words: audit quality; managerial; firm size

\section{Latar Belakang}

\section{PENDAHULUAN}

Menurut (Akram, Basuki, \& Budiarto, 2017) Laporan keuangan adalah informasi keuangan di suatu perusahaan. Laporan keuangan merupakan laporan mengenai kinerja keuangan perusahaan yang wajib dibuat oleh perusahaan. Laporan keuangan perusahaan disusun untuk menyampaikan informasi mengenai kondisi keuangan serta kinerja dan perubahan kondisi keuangan di suatu perusahaan pada periode tertentu. Sebelum laporan keuangan perusahaan dipublikasikan, terlebih dahulu harus diaudit. Fungsi audit disini adalah untuk memeriksa apakah angka-angka yang disajikan dalam laporan keuangan yang disusun oleh perusahaan sudah disajikan dengan nilai wajar ataukah tidak. Integritas laporan keuangan merupakan laporan keuangan yang menampilkan kondisi perusahaan yang sebenarnya, tanpa ada yang disembunyikan atau ditutupi.

Kasus yang baru terjadi pada PT Tiga Pilar Sejahtera Food Tbk (AISA), perusahaan telah melakukan tindakan fraud yaitu merekayasa laporan keuangan tahun 2017 dengan menggelembungkan laba bersih perusahaan dan menyebabkan harga saham perusahaan yang melonjak, tindakan kecurangan ini telah membawa kerugian terhadap investor dan para pemangku kepentingan lainnya. Berdasarkan analisa perbandingan laporan keuangan tahun 2017 sebelumnya dengan laporan setelah disajikan kembali terdapat penggelembungan dengan total lebih dari 5 triliun rupiah terutama pada akun aset tetap terdapat penggelembungan sebesar Rp 2,35 triliun, akun piutang usaha sebesar Rp 1,63 triliun dan akun persediaan sebesar Rp 1,31 triliun. Peningkatan piutang usaha tentu akan menyebabkan penggelembungan pada akun penjualan neto yang berselisih cukup besar sejumlah Rp 2,97 triliun. Dari proses persidangan kasus ditemukan adanya dugaan pelarian dana ke perusahaan milik manajemen lama yang seharusnya sebagai pihak berelasi akan tetapi dilapor hanya sebagai pihak ketiga 
dan menggunakan dana hasil pencairan pinjaman dan deposito yang sebagai gantinya direkayasa dengan meningkatkan angka piutang usaha sebagai hutang yang belum tertagih. Dengan ini dapat ditemukan bahwa AISA telah melakukan pelanggaran dengan mengakui adanya pendapatan fiktif sebagai pendapatan dengan mencatat penjualan yang tidak memiliki substansi ekonomi dimana penjualan tersebut dari arti ekonomisnya tidak pernah terjadi transaksinya sehingga tidak boleh diakui sebagai pendapatan perusahaan. Manajemen lama mencatat dana hasil pencairan pinjaman sebagai piutang usaha yaitu mengakui kas diterima dalam transaksi pinjaman sebagai pendapatan.

Banyak faktor yang mempengaruhi integritas laporan keuangan diantaranya adalah Struktur Kepemilikan, Komite Audit, komisaris independen, Dewan Direksi, Audit quality, Manajemen Laba, Firm size, Audit Tenure, Reputasi KAP, Laverage dan Good Corporate Governance (Paramita Hana Saksakotama, 2014) Pada penelitian ini bermaksud untuk mengetahui adakah pengaruh antara kepemilikan manajerial, ukuran perusahaan dan kualitas audit terhadap integritas laporan keuangan.

Kepemilikan manajerial yaitu proporsi pemegang saham dari pihak manajemen yang secara aktif ikut dalam pengambilan keputusan perusahaan. Adanya kepemilikan saham pihak manajemen perusahaan maka manajer akan meningkatkan kinerjanya serta lebih berhati-hati untuk mengambil keputusan dalam mengelola perusahaan termasuk menetapkan integritas laporan keuangan. Berdasarkan penelitian (Febriyanti \& Wahidahwati, 2020), (Arista, Wahyudi, \& Yusnaini, 2018) menemukan kepemilikan manajerial berpengaruh terhadap integritas laporan keuangan. Penelitian (Fajar \& Nurbaiti, 2020), (Wardhani \& Samrotun, 2020), menunjukkan bahwa variabel kepemilikan manajerial tidak berpengaruh terhadap integritas laporan keuangan.

Ukuran perusahaan menurut (Sudarmadji \& Sularto, 2007) yaitu besar kecilnya suatu perusahaan yang bisa ditinjau dari total aset, penjualan, serta kapitalisasi pasar. Semakin besar perusahaan biasanya memiliki pengalaman yang lebih baik dalam penyusunan laporan keuangan. Dalam perusahaan besar tuntutan stakeholder atas pengungkapan informasi laporan keuangan yang jujur juga akan semakin besar sehingga akan lebih berhati-hati dalam menetapkan laporan keuangan. Penelitian (Fajar \& Nurbaiti, 2020), (Febrilyantri \& Candra, 2020), menemukan bahwa ukuran perusahaan berpengaruh terhadap integritas laporan keuangan. Penelitian (Juliana \& Radita, 2019), (Wardhani \& Samrotun, 2020), (Mais \& Fadlan, 2016), menemukan bahwa ukuran perusahaan tidak berpengaruh terhadap integritas laporan keuangan.

Kualitas audit adalah kemampuan auditor untuk menemukan kecurangan atau kesalahan pada sistem akuntansi. Untuk mendeteksi adanya tindak kecurangan maupun error pada sebuah laporan keuangan dapat dilakukan melalui proses audit . Kantor akuntan publik (KAP) yang masuk sebagai big four pada umumnya mempunyai reputasi serta pengalaman yang lebih baik dari pada KAP non big four. Penelitian (Badewin, 2019), (Akram, Basuki, \& Budiarto, 2017), (Febriyanti \& Wahidahwati, 2020), dan (Juliana \& Radita, 2019), menemukan bahwa kualitas audit berpengaruh terhadap integritas laporan keuangan. Penelitian (Ayem \& Yuliana, 2019) dan (Danuta \& Wijaya, 2020), menemukan bahwa kualitas audit tidak berpengaruh terhadap integritas laporan keuangan.

\section{Rumusan Masalah}

Berdasarkan latar belakang masalah maka rumusan masalah adalah apakah kepemilikan manajerial, ukuran perusahaan dan kualitas audit berpengaruh pada integritas laporan keuangan pada perusahaan manufaktur subsektor makanan dan minuman yang terdaftar di bursa efek indonesia (BEI). 


\section{Tujuan Penelitian}

Berdasarkan latar belakang maka tujuan penelitian adalah untuk mengetahui dan menganalisis pengaruh kepemilikan manajerial, ukuran perusahaan dan kualitas audit terhadap integritas laporan keuangan pada perusahaan manufaktur subsektor makanan dan minuman yang terdaftar di bursa efek Indonesia (BEI).

\section{Agency Theory}

Agency Theory (teori agensi) dikembangkan (Jensen, M. C., \& Meckling, W. H., 1976) bahwa hubungan kerja antara agent (manajemen) serta principal (pemegang saham). hubungan keagenan tersebut terkadang menimbulkan permasalahan antara pemegang saham dan manajer. berdasarkan teori tersebut, adanya pemisahan antara kepemilikan serta pengelolaan perusahaan dapat mengakibatkan konflik. konflik yang terjadi karena manusia ialah makhluk ekonomi yang memiliki sifat dasar mementingkan kepentingan diri sendiri untuk memanipulasi laporan keuangan supaya jumlah laba sesuai dengan harapan pihak manajer. karena hal tersebut laba yang dilaporkan tidak menunjukkan kinerja perusahaan yang sesungguhnya sehingga dapat menyesatkan para pengguna laporan keuangan.

\section{Integritas Laporan Keuangan}

Laporan keuangan menggambarkan keseluruhan transaksi usaha sepanjang waktu yangi menghasilkan, baik peningkatan maupun penurunan bersih nilai ekonomi bagi pemilik modal. Laporan keuangan adalah media yang paling penting untuk menilai kondisi keuangan suatu perusahaan. Integritas laporan keuangan artinya laporan keuangan yang menampilkan kondisi perusahaan sebenarnya, tanpa ada yang disembunyikan. Mengacu di kasus-kasus perusahaan publik di Indonesia bisa disimpulkan rendahnya integritas laporan keuangan menjadi penyebab perusahaan publik mempunyai integritas laporan keuangan yang buruk.

\section{Kepemilikan Manajerial}

Menurut (Jensen, M. C., \& Meckling, W. H. , 1976) menemukan bahwa kepemilikan manajerial berhasil mengurangi problem keagenan dari manajer dengan mengimbangkan kepentingan manajer dengan pemegang saham. Kepemilikan manajerial ialah besarnya persentase saham yang dimiliki oleh manajemen. Kepemilikan manajerial menunjukkan adanya peran ganda seorang manajer pada suatu perusahaan, yakni menjadi manajer serta menjadi pemegang saham. Perusahaan memberikan kesempatan pada manajer untuk mempunyai sebagian saham perusahaan. Keputusan ini dilakukan untuk mempertahankan manajer yang memiliki kinerja baik serta mengarahkan manajer supaya bertindak sesuai dengan tujuan perusahaan yaitu menaikkan kesejahteraan pemegang saham.

\section{Ukuran Perusahaan}

Menurut (Sudarmadji \& Sularto, 2007) ukuran perusahaan ialah besar kecilnya suatu perusahaan yang bisa ditinjau dari total aset, penjualan, serta kapitalisasi pasar. ukuran menggambarkan kemampuan operasi perusahaan, seperti efektivitas pengendalian internal serta tata kelola perusahaan. ukuran juga menggambarkan reputasi perusahaan. Perusahaan yang berukuran besar umumnya mempunyai peran sebagai pemegang kepentingan yang lebih luas. Perusahaan besar juga memberikan kemampuan perusahaan dengan tindakan pengambilan keputusan (Paramita Hana Saksakotama, 2014). Banyaknya tuntutan dari stakeholder yang akan diterima oleh perusahaan skala besar umtuk laporan keuangan yang mempunyai integritas tinggi, diharapkan bisa mengurangi manajemen dalam praktek kecurangan dan menyampaikan informasi keuangan. 


\section{Kualitas Audit}

Menurut (Juliana \& Radita, 2019) audit adalah proses yang menilai kewajaran laporan keuangan. Auditor yang melakukan jasa audit ini adalah jasa assurance yang berfungsi untuk menaikkan kualitas informasi keuangan perusahaan. Auditor dalam menyampaikan opini untuk menilai kewajaran laporan keuangan wajib seorang yang independen atau pihak eksternal perusahaan. berafiliasi dengan jasa yang diberikan oleh auditor, kualitas audit yang diberikan akan menyampaikan pengaruh terhadap kualitas laporan keuangan atau integritas laporan keuangan. Kualitas audit ini sangat penting sebab kualitas audit yang tinggi akan menghasilkan laporan keuangan yang dapat dipercaya menjadi dasar pengambilan keputusan. untuk mengukur kualitas audit dengan mengklasifikasi antara jasa audit dari KAP big four dengan KAP non big four KAP yang besar mempunyai reputasi serta pengalaman yang lebih baik daripada KAP yang kecil. Auditor pada KAP besar disebut lebih akurat dibandingkan menggunakan auditor yang bekerja pada KAP yang kecil.

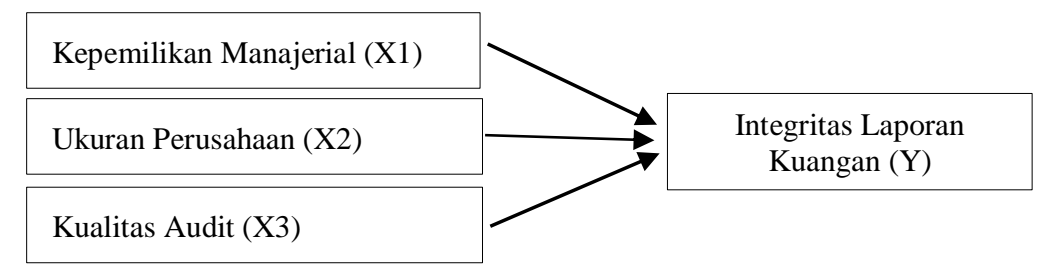

\section{Hipotesis}

\section{Pengaruh Kepemilikan Manajerial Terhadap Integritas Laporan Keuangan}

Kepemilikan manajerial merupakan proporsi pemegang saham dari pihak manajemen yang secara aktif ikut pada pengambilan keputusan perusahaan. Kepemilikan manajerial yang memiliki presentase besar pada suatu perusahaan manajer akan merasakan langsung manfaat dari keputusan yang sudah diambil baik keputusan pengambilan yang benar maupun keputusan pengambilan yang keliru. adanya kepemilikan saham oleh manajemen perusahaan membuat manajer lebih berhati-hati untuk menghasilkan keputusan dalam mengelola perusahaan termasuk pada menetapkan integritas laporan keuangan. Penelitian (Febriyanti \& Wahidahwati, 2020), (Arista, Wahyudi, \& Yusnaini, 2018), menemukan kepemilikan manajerial berpengaruh terhadap integritas laporan keuangan. Penelitian (Fajar \& Nurbaiti, 2020), (Wardhani \& Samrotun, 2020), (Sinulingga, Wijaya, \& Wibawaningsih, 2020) menunjukkan bahwa variabel kepemilikan manajerial tidak berpengaruh terhadap integritas laporan keuangan. Berdasarkan hal tersebut maka hipotesis pertama adalah:

\section{H1 : Kepemilikan manajerial berpengaruh terhadap integritas laporan keuangan}

\section{Pengaruh Ukuran Perusahaan Terhadap Integritas Laporan Keuangan}

Perusahaan biasanya memiliki pengalaman yang lebih baik dalam penyusunan laporan keuangan. Dalam perusahaan besar tuntutan stakeholder atas pengungkapan informasi laporan keuangan yang jujur juga akan semakin besar. Ukuran perusahaan bisa menggambarkan informasi yang terdapat di dalam perusahaan serta pentingnya informasi tersebut bagi pihakpihak baik internal maupun eksternal. Perusahaan yang berukuran besar akan semakin tinggi tingkat pengungkapan informasi diperusahaan tersebut. Penelitian (Fajar \& Nurbaiti, 2020), (Febrilyantri \& Candra, 2020), (Febriyanti \& Wahidahwati, 2020) menemukan bahwa ukuran perusahaan berpengaruh terhadap integritas laporan keuangan. Penelitian (Juliana \& Radita, 2019), (Wardhani \& Samrotun, 2020), (Mais \& Fadlan, 2016), menemukan bahwa ukuran perusahaan tidak berpengaruh terhadap integritas laporan keuangan. Berdasarkan hal tersebut maka hipotesis kedua adalah:

H2 : Ukuran Perusahaan berpengaruh terhadap integritas laporan keuangan 


\section{Pengaruh Kualitas Audit Terhadap Integritas Laporan Keuangan}

Kualitas audit merupakan proses susunan atau aturan untuk memperoleh serta mengevaluasi bukti secara objektif tentang pernyataan aktivitas serta kejadian ekonomi, dengan tujuan untuk menetapkan tingkat kesesuaian antara pernyataan-pernyataan tersebut dengan kriteria yang telah ditetapkan, serta penyampaian hasil pada pemakai yang berkepentingan (Mulyadi, 2011). KAP yang besar mempunyai reputasi serta pengalaman yang lebih baik dari pada KAP yang kecil. Auditor pada KAP besar dianggap lebih akurat dibandingkan menggunakan auditor yangi bekerja di KAP yang kecil. Berdasarkan uraian di atas kualitas audit berpengaruh terhadap integritas laporan keuangan. Hal ini didukung temuan penelitian (Badewin, 2019), (Akram, Basuki, \& Budiarto, 2017), (Febriyanti \& Wahidahwati, 2020) dan (Juliana \& Radita, 2019) menemukan bahwa kualitas audit berpengaruh terhadap integritas laporan keuangan. Penelitian (Ayem \& Yuliana, 2019) dan (Danuta \& Wijaya, 2020), menemukan bahwa kualitas audit tidak berpengaruh terhadap integritas laporan keuangan. Berdasarkan hal tersebut maka hipotesis ketiga adalah:

\section{H3 : Kualitas Audit berpengaruh terhadap integritas laporan keuangan}

\section{Penelitian Terdahulu}

\section{STUDI LITERATUR}

1. Pengaruh Corporate Governance Dan Ukuran Perusahaan Terhadap Integritas Laporan Keuangan (Muhammad Fajar dan Annisa Nurbaiti 2020. Junal Mitra Manajemen Edisi Juni. Vol 4 No 6)

2. Pengaruh Kepemilikan Institusional, Kepemilikan Manajerial, Ukuran Perusahaan dan Leverage terhadap Integritas Laporan Keuangan (Widya Kusuma Wardhani dan Yuli Chomsatu Samrotun. 2020. Jurnal Ilmiah Universitas Batanghari Jambi. Vol 20 No 2)

3. Pengaruh Kepemilikan Manajerial, Leverage, Dan Kualitas Audit Terhadap Integritas Laporan Keuangan (Krisnhoe Sukma Danuta dan Minadi Wijaya 2020. Majalah Ilmiah Manajemen Dan Bisnis. Vol 17 No 1)

\section{Populasi dan Sampel}

\section{METODE}

Populasi merupakan seluruh jumlah sasaran pengamatan yang akan diuji (Bahri, 2018) Populasi penelitian adalah perusahaan sub sektor makanan dan minuman periode 2017-2020 yang terdaftar di Bursa Efek Indonesia. Pengambilan sampel purposive sampling dengan pemilihan sampel sebagai berikut:

1. Perusahaan manufaktur sub sektor makanan dan minuman yang terdaftar di BEI periode 2017-2020.

2. Perusahaan sub sektor makanan dan minuman yang listing secara konsisten di Bursa Efek Indonesia selama periode 2017-2020.

3. Perusahaan sub sektor makanan dan minuman yang memperoleh laba dan sebagai sampel penelitian periode 2017-2020.

\section{Definisi Operasional}

1. Integritas laporan keuangan dapat diindikasikan dengan kemampuan perusahaan dalam mengolah laporan keuangannya harus benar-benar akurat dan terhindar dari manipulasi data keuangannnya. Pada umumnya untuk mengukur integritas laproan keuangan yang baik diukur dengan pengukuran konsevatisme akuntansi dengan menggunakan indeks konsevatif dengan menggunakan proksi market to book value of equity. Rasio ini merupakan perbandingan antara nilai pasar ekuitas dengan nilai buku ekuitas. Rasio yang bernilai lebih dari 1, mengindikasikan akuntansi yang konservatif karena perusahaan 
mencatat nilai perusahaan lebih rendah dari nilai pasarnya sehinngga membuat intergitas laporan keuangan semakin rendah (Ayem \& Yuliana, 2019)

$$
\text { Market to Book/ILKIT }=\frac{\text { harga pasar per saham }}{\text { nilai buku per saham }}
$$

2. Kepemilikan manajerial adalah pemegang saham dari pihak manajemen yang selalu aktif ikut dalam pengambilan keputusan perusahaan (Badewin, 2019). Kepemilikan manajerial diproksikan dengan manajerial ownership (MOWN).

Manajerial ownership $=\frac{\text { Saham Manajer }}{\text { Jumlah saham beredar }} \times 100 \%$

3. Ukuran Perusahaan menggambarkan informasi yang terdapat di dalam perusahaan dan pentingnya informasi tersebut bagi pihak internal maupun eksternal. Ukuran perusahaan diproksikan dengan Ln total aset perusahaan yaitu jumlah keseluruhan aset yang perusahaan miliki pada periode tertentu.

4. Kualitas Audit. Menurut (Juliana \& Radita, 2019) audit adalah proses yang menilai kewajaran laporan keuangan. Untuk mengukur kualitas audit dapat mengklasifikasi antara jasa audit dari KAP big four dengan KAP non big four. Dimana KAP yang besar memiliki reputasi dan pengalaman yang lebih baik dari pada KAP yang kecil. Auditor di KAP besar dianggap lebih akurat dibandingkan dengan auditor yang bekerja di KAP yang kecil

\section{Statistic Deskriptif}

\section{HASIL}

Analisis statistik deskriptif digunakan untuk mendeskripsikan suatu data berdasarkan nilai minimum, maksimum, rata-rata (mean), serta standar deviasi dari setiap variabel. Berdasarkan analisis statistik deskriptif diperoleh data sebagai berikut:

\begin{tabular}{|l|c|r|r|r|r|}
\hline & $\mathrm{N}$ & Minimum & Maximum & \multicolumn{1}{c|}{ Mean } & \multicolumn{1}{c|}{ Std. Deviation } \\
\hline ILK & 64 & .00 & 1.00 & .9844 & .12500 \\
Kepemilikan Manajerial & 64 & 50.00 & 100.00 & 77.8125 & 13.18474 \\
Ukuran Perusahaan & 64 & 2708.00 & 3273.00 & 2876.0312 & 143.18519 \\
Kualitas Audit & 64 & .00 & 1.00 & .3594 & .48361 \\
Valid N (listwise) & 64 & & & & \\
\hline
\end{tabular}

Berdasarkan tabel di atas bisa dideskripsikan bahwa jumlah data yang diolah (N) adalah 64. Dan bisa diketahui nilai minimum, nilai maksimum, rata-rata dan simpangan baku dari masing-masing data penelitian.

Kepemilikan manajerial memiliki nilai minimum sebesar 50,00; nilai maksimum sebesar 100,00; rata-rata sebesar 77,8125 dan simpangan baku sebesar 13,18474. Ukuran perusahaan memiliki nilai minimum sebesar 2708,00; nilai maksimum sebesar 3273,00; rata-rata sebesar 2876,0312 dan simpangan baku sebesar 143,18519. Kualitas audit memiliki nilai minimum sebesar 0; nilai maksimum sebesar 1,00; rata-rata sebesar 0,3594 dan simpangan baku sebesar 0,48361 .

\section{Uji Kelayakan Model Regresi}

Kelayakan model regresi digunakan untuk mengetahui seberapa baik hasil dari regresi logistik. Kelayakan model regresi dinilai berdasarkan uji Hosmer and Lemeshow Test jika hasil uji > 0,05 maka model memiliki kemampuan untuk memprediksi nilai observasi atau dengan kata lain model dapat diterima karena sesuai dengan data observasi, begitupula sebaliknya. Berikut uji kelayakan model regresi 
Hosmer and Lemeshow Test

\begin{tabular}{|l|r|r|r|}
\hline Step & Chi-square & Df & \multicolumn{1}{c|}{ Sig. } \\
\hline 1 & .543 & & 8 \\
\hline
\end{tabular}

Berdasarkan uji Hosmer and Lemeshow Test diperoleh 1,000 sehingga nilai Hosmer and Lemeshow Test > 0,05 menunjukkan jika $\mathrm{H} 1$ dari uji kelayakan model regresi diterima. Hal ini berati model tidak memiliki perbedaan dengan nilai observasinya sehingga layak digunakan buat analisis selanjutnya.

\section{Uji Fit Keseluruhan Model}

Pengujian model fit dan keseluruhan model dilakukan untuk menunjukkan model regresi yang baik atau dengan kata lain model yang dihipotesiskan fit dengan data (Ghozali, 2016). Pengujian dilakukan untuk menilai keseluruhan model (overall model fit) yang telah dihipotesiskan secara keseluruhan fit dengan data. Pengujian ini dilakukan dengan membandingkan nilai -2 Log likelihood awal (Block number $=0$ ) dengan nilai -2 Log likelihood akhir (Block number $=1$ ) yang disajikan dalam tabel berikut:

\begin{tabular}{|ll|r|c|}
\hline \multicolumn{3}{|c|}{ Iteration History $\mathbf{y}^{\mathbf{a}, \mathbf{b}, \mathbf{c}}$} \\
\cline { 4 - 4 } Iteration & & & Coefficients \\
\cline { 4 - 4 } & & -2 Log likelihood & Constant \\
\hline & 1 & 21.102 & 1.938 \\
& 2 & 12.476 & 2.940 \\
& 3 & 10.566 & 3.665 \\
4 & 10.311 & 4.049 \\
& 5 & 10.302 & 4.139 \\
6 & 10.302 & 4.143 \\
7 & 10.302 & 4.143 \\
\hline
\end{tabular}

Iteration History $y^{\mathrm{a}, \mathrm{b}, \mathrm{c}, \mathrm{d}}$

\begin{tabular}{|c|c|c|c|c|c|c|}
\hline \multirow[b]{2}{*}{ Iteratio } & & \multirow[b]{2}{*}{-2 Log likelihood } & \multicolumn{4}{|c|}{ Coefficients } \\
\hline & & & Constant & $\begin{array}{c}\text { Kepemilikan } \\
\text { Manajerial }\end{array}$ & $\begin{array}{c}\text { Ukuran } \\
\text { Perusahaan }\end{array}$ & $\begin{array}{c}\text { Kualitas } \\
\text { Audit }\end{array}$ \\
\hline \multirow[t]{20}{*}{ Step 1} & 1 & 20.802 & .003 & .009 & .000 & .060 \\
\hline & 2 & 11.585 & -2.780 & .026 & .001 & .178 \\
\hline & 3 & 8.729 & -9.394 & .059 & .003 & .407 \\
\hline & 4 & 7.634 & -18.613 & .100 & .005 & .725 \\
\hline & 5 & 7.235 & -27.083 & .138 & .007 & 1.119 \\
\hline & 6 & 7.121 & -33.074 & .163 & .009 & 1.690 \\
\hline & 7 & 7.092 & -35.491 & .173 & .010 & 2.518 \\
\hline & 8 & 7.083 & -35.817 & .174 & .010 & 3.496 \\
\hline & 9 & 7.080 & -35.830 & .174 & .010 & 4.495 \\
\hline & 10 & 7.079 & -35.831 & .174 & .010 & 5.495 \\
\hline & 11 & 7.078 & -35.831 & .174 & .010 & 6.495 \\
\hline & 12 & 7.078 & -35.831 & .174 & .010 & 7.495 \\
\hline & 13 & 7.078 & -35.831 & .174 & .010 & 8.495 \\
\hline & 14 & 7.078 & -35.831 & .174 & .010 & 9.495 \\
\hline & 15 & 7.078 & -35.831 & .174 & .010 & 10.495 \\
\hline & 16 & 7.078 & -35.831 & .174 & .010 & 11.495 \\
\hline & 17 & 7.078 & -35.831 & .174 & .010 & 12.495 \\
\hline & 18 & 7.078 & -35.831 & .174 & .010 & 13.495 \\
\hline & 19 & 7.078 & -35.831 & .174 & .010 & 14.495 \\
\hline & 20 & 7.078 & -35.831 & .174 & .010 & 15.495 \\
\hline
\end{tabular}

Berdasarkan tabel di atas diperoleh hasil

-2 LL awal (Block Number $=0$ ) sebesar 10,302 
-2LL akhir (Block Number $=1$ ) sebesar 7,078

Berdasarkan tabel di atas menunjukkan nilai -2LL awal (Block number $=0$ ) adalah 10,302 dan mengalami penurunan pada nilai -2LL akhir (Block number $=1$ ) menjadi 7,078. Penurunan nilai -2 Log Likelihood menunjukkan model yang diregresikan baik atau model yang dihipotesiskan fit dengan data.

\section{Koefesien Determinasi}

Koefisien determinasi (Nagelkerke R Square) digunakan untuk memperlihatkan seberapa besar variabilitas variabel-variabel independen mampu menjelaskan variabilitas dependen. Besarnya nilai koefisien determinasi pada model regresi logistik ditunjukkan oleh nilai Nagelkerke R Square (Ghozali, 2016).

\begin{tabular}{|c|c|c|c|}
\hline \multicolumn{4}{|c|}{ Model Summary } \\
\hline Step & -2 Log likelihood & $\begin{array}{l}\text { Cox \& Snell R } \\
\text { Square }\end{array}$ & $\begin{array}{c}\text { Nagelkerke R } \\
\text { Square }\end{array}$ \\
\hline 1 & $7.078^{a}$ & .049 & .330 \\
\hline
\end{tabular}

Berdasarkan tabel di atas nilai Nagelkerke R Square yang dihasilkan sebesar 0,330. Nilai tersebut diinterpretasikan sebagai kemampuan variabel independen secara bersama-sama mempengaruhi variabel dependen sebesar 33,0\%, sedangkan sisanya 67,0\% dijelaskan oleh variabel lain di luar penelitian atau secara bersama-sama variabel Kepemilikan manajerial, ukuran perusahaan dan kualitas audit dapat menjelaskan variabel dependen integritas laporan keuangan sebesar 33,0\%.

\section{Matrik Klasifikasi}

Matrik klasifikasi menunjukan kekuatan prediski model regresi untuk memprediksi kemungkinkan penerimaan integritas laporan keuangan

\begin{tabular}{|c|c|c|c|c|c|}
\hline \multicolumn{6}{|c|}{ Classification Table $^{\mathrm{a}, \mathrm{b}}$} \\
\hline & \multirow[b]{3}{*}{ Observed } & & \multicolumn{3}{|c|}{ Predicted } \\
\hline & & & \multicolumn{2}{|c|}{$\mathrm{Y}$} & \multirow[b]{2}{*}{ Percentage Correct } \\
\hline & & & $\begin{array}{c}\text { INTEGRITAS } \\
\text { RENDAH }\end{array}$ & $\begin{array}{c}\text { INTEGRITAS } \\
\text { TINGGI }\end{array}$ & \\
\hline \multirow[t]{3}{*}{ Step 0} & Integritas Laporan & INTEGRITAS RENDAH & 0 & 1 & .0 \\
\hline & Keuangan & INTEGRITAS TINGGI & 0 & 63 & 100.0 \\
\hline & Overall Percentage & & & & 98.4 \\
\hline
\end{tabular}

Berdasarkan tabel diatas dapat diketahui bahwa kemampuan model memprediksi integritas laporan keuangan sebesar 98,4\%.

\section{Uji Hipotesis}

Pengujian hipotesis pada penelitian ini menggunakan pengujian koefisien regresi logistik dengan tingkat signifikasi 5\% atau 0,05 yang disajikan dalam tabel dibawah ini :

\begin{tabular}{|c|c|c|c|c|c|c|c|}
\hline & & B & S.E. & Wald & df & Sig. & $\operatorname{Exp}(B)$ \\
\hline \multirow[t]{4}{*}{ Step $1^{\mathrm{a}}$} & $\begin{array}{l}\text { Kepemilikan } \\
\text { Manajerial }\end{array}$ & .174 & .191 & .828 & 1 & .363 & 1.190 \\
\hline & $\begin{array}{l}\text { Ukuran } \\
\text { Perusahaan }\end{array}$ & .010 & .027 & .132 & 1 & .716 & 1.010 \\
\hline & Kualitas Audit & 15.495 & 7845.259 & .000 & 1 & .998 & 5362825.923 \\
\hline & Constant & -35.831 & 85.326 & .176 & 1 & .675 & .000 \\
\hline
\end{tabular}

a. Variable(s) entered on step 1: manajerial, ukuran perusahaan, kualitas audit 


\section{PEMBAHASAN}

Nilai signifikansi kepemilikan manajerial dari hasil pengujian lebih dari 0,05 , yaitu sebesar 0,363 atau lebih besar dari tingkat signifikansi $(0,363>0,05)$ yang berarti bahwa H1 tidak terdapat pengaruh yang signifikan terhadap integritas laporan keuangan. Dapat dikatakan kondisi kepemilikan manajerial tidak berpengaruh terhadap integritas laporan keuangan. Karena kepemiilikan saham yang dimiliki pihak manajemen tidak menjamin laporan tersebut berintegritas, namun akan meningkatkan kinerja manajemen tersebut dalam pengungkapan laporan keuangan. Pada dasarnya para pemegang saham memiliki kedudukan yang sama. Hasil penelitian didukung oleh penelitian (Febriyanti \& Wahidahwati, 2020), (Arista, Wahyudi, \& Yusnaini, 2018) menemukan kepemilikan manajerial berpengaruh terhadappintegritas laporan keuangan dan tidak sejalan dengan penelitian (Fajar \& Nurbaiti, 2020), (Wardhani \& Samrotun, 2020), (Sinulingga, Wijaya, \& Wibawaningsih, 2020) menunjukkan bahwa variabel kepemilikan manajerial tidak berpengaruh terhadap integritas laporan keuangan.

Nilai signifikansi ukuran perusahaan dari hasil pengujian kurang dari 0,05 , yaitu sebesar 0,716 atau lebih besar dari tingkat signifikansi $(0,716>0,05)$ yang berarti bahwa $\mathrm{H} 2$ tidak terdapat pengaruh yang signifikan terhadap integritas laporan keuangan. Dapat dikatakan kondisi ukuran perusahaan tidak berpengaruh terhadap integritas laporan keuangan. Karena tidak semua perusahaan besar memiliki pengalaman yang lebih baik dalam penyusunan laporan keuangan dan memungkinkan juga perusahaan kecil memiliki pengalaman yang lebih baik dalam melaporkan integritas laporan keuangan. Hasil penelitian didukung oleh (Juliana \& Radita, 2019), (Wardhani \& Samrotun, 2020), menemukan bahwa ukuran perusahaan berpengaruh terhadap integritas laporan keuangan dan tidak sejalan dengan penelitian (Khoirunisa \& Anhar, 2020) penelitian (Fajar \& Nurbaiti, 2020), (Febrilyantri \& Candra, 2020), menemukan bahwa ukuran perusahaan tidak berpengaruh terhadap integritas laporan keuangan.

Nilai signifikansi kualitas audit dari hasil pengujian kurang dari 0,05 , yaitu sebesar 0,998 atau lebih besar dari tingkat signifikansi $(0,998>0,05)$ yang berarti bahwa $\mathrm{H} 3$ tidak terdapat pengaruh yang signifikan terhadap integritas laporan keuangan. dapat dikatakan syarat kualitas audit tidak berpengaruh terhadap integritas laporan keuangan karena pemilihan KAP big four atau non big four selaku pihak eksternal perusahaan yang mengaudit laporan keuangan dalam perusahaan sudah baik karena KAP manapun mempunyai standar yang sama sesuai pada standar Profesional Akuntansi (SPAP) sehingga KAP manapun tidak mempengaruhi suatu integritas laporan keuangan. Dan hasil penelitian didukung oleh penelitian (Ayem \& Yuliana, 2019), (Danuta \& Wijaya, 2020) menemukan bahwa kualitas audit tidak berpengaruh terhadap integritas laporan keuangan dan tidak sejalan dengan penelitian (Badewin, 2019), (Akram, Basuki, \& Budiarto, 2017), dan (Juliana \& Radita, 2019) menemukan bahwa kualitas audit berpengaruh terhadap integritas laporan keuangan.

\section{KESIMPULAN}

Proporsi pemegang saham dari pihak manajemen atau kepemilikan manajerial tidak dapat dijadikan faktor pengaruh terhadap integritas laporan keuangan. Ukuran perusahaan yang diproksikan dengan total aset tidak berpengaruh signifikan terhadap integritas laporan keuangan karena tidak semua perusahaan besar memiliki tingkat pengungkapan informasi yang tinggi. Kualitas audit yang diproksikan dengan mengklisifikasikan KAP bigfour dan KAP non bigfour tidak berpengaruh signifikan terhadap integritas laporan keuangan karena semua KAP memiliki standar yang sama sesuai dalam Standar Profesional Akuntansi (SPAP) yang sudah ditetapkan. 


\section{REFERENSI}

Akram, Basuki, P., \& Budiarto. (2017). Pengaruh Mekanisme Corporate Governance, Kualitas Audit, Ukuran Perusahaan dan Leverage Terhadap Integritas Laporan Keuangan. JAA.

Arista, S., Wahyudi, T., \& Yusnaini. (2018). PENGARUH STRUKTUR CORPORATE GOVERNANCE DAN AUDIT TENURE TERHADAP INTEGRITAS LAPORAN KEUANGAN. Jurnal Penelitian dan Pengembangan Akuntansi, Vol.12 No.2.

Ayem, S., \& Yuliana, D. (2019). PENGARUH INDEPENDENSI AUDITOR, KUALITAS AUDIT, MANAJEMEN LABA, DAN KOMISARIS INDEPENDEN TERHADAP INTEGRITAS LAPORAN KEUANGAN. Jurnal Akuntansi \& Manajemen Akmenika , Vol. 16 No. 1.

Badewin. (2019). PENGARUH KEPEMILIKAN INSTITUSIONAL, KOMITE AUDIT DAN KUALITAS AUDIT TERHADAP INTEGRITAS LAPORAN KEUANGAN PADA PERUSAHAAN MANUFAKTUR YANG TERDAFTAR DI BEI. Jurnal Akuntansi dan Keuangan, Vol. 8, N0. 1.

Bahri, S. (2018). Metodoloogi Penelitian Bisnis - Lengkap dengan Teknik Pengelolaan data SPSS. Penerbit Andi.

Danuta, K. S., \& Wijaya, M. (2020). PENGARUH KEPEMILIKAN MANAJERIAL, LEVERAGE, DAN KUALITAS AUDIT TERHADAP INTEGRITAS LAPORAN KEUANGAN. MANAJEMEN \& BISNIS.

Fajar, M., \& Nurbaiti, A. (2020). PENGARUH CORPORATE GOVERNANCE DAN UKURAN PERUSAHAAN TERHADAP INTEGRITAS LAPORAN KEUANGAN. Jurnal Mitra Manajemen (JMM Online), Vol. 4, No. 6.

Febrilyantri, \& Candra. (2020). Pengaruh Intellectual Capital, Size dan Leverage Terhadap Integritas Laporan Keuangan Pada Perusahaan Manufaktur Sektor Food and Beverage Tahun 2015-2018. Owner RISET \& JURNAL AKUNTANSI, Volume 4 Nomor 1.

Febriyanti, N., \& Wahidahwati. (2020). PENGARUH CORPORATE GOVERNANCE, LEVERAGE DAN INVESTMENT OPPORTUNITY SET TERHADAP INTEGRITAS LAPORAN KEUANGAN. Jurnal Ilmu dan Riset Akuntansi.

Ghozali, I. (2016). Aplikasi Analisis Multivariete dengan Program IBM SPSS 23. . Badan Penerbit Universitas Diponegoro Semarang.

Jensen, M. C., \& Meckling, W. H. . (1976). Theory of the Firm : Managerial Behavior, Agency Costs and Ownership Structure Theory of the Firm: Managerial Behavior. Agency Costs and Ownership Structure.

Juliana, \& Radita, M. (2019). PENGARUH CORPORATE GOVERNANCE, UKURAN PERUSAHAAN, DAN KUALITAS AUDIT TERHADAP INTEGRITAS LAPORAN KEUANGAN. JURNAL ILMIAH WAHANA AKUNTANSI, Vol 14 (2).

Khoirunisa, F., \& Anhar. (2020). Pengaruh Mekanisme Good Corporate Governance dan Ukuran Perusahaan Terhadap Integritas Laporan Keuangan. Sekolah Tinggi Ilmu Ekonomi Indonesia.

Mais, R. G., \& Fadlan, N. (2016). PENGARUH GOOD CORPORATE GOVERNANCE, UKURAN PERUSAHAAN, DAN LEVERAGE TERHADAP INTEGRITAS LAPORAN KEUANGAN. JRAK.

Mulyadi. (2011). PENELITIAN KUANTITATIF DAN KUALITATIF SERTA PEMIKIRAN DASAR MENGGABUNGKANNYA. Jurnal studi komunikasi dan media.

Paramita Hana Saksakotama, N. C. (2014). DETERMINAN INTEGRITAS LAPORAN KEUANGAN PERUSAHAAN MANUFAKTUR DI INDONESIA. DIPONEGORO JOURNAL OF ACCOUNTING, 1-13.

Sinulingga, J. I., Wijaya, S. Y., \& Wibawaningsih, E. J. (2020). PENGARUH KEPEMILIKAN INSTITUSIONAL, KEPEMILIKAN MANAJERIAL DAN 
UKURAN KANTOR AKUNTAN PUBLIK TERHADAP INTEGRITAS LAPORAN KEUANGAN. Jurnal Syntax Transformation, Vol. 1 No. 8.

Sudarmadji, A. M., \& Sularto, L. (2007). Pengaruh Ukuran Perusahaan, Profitabilitas, Leverage dan Tipe Kepemilikan Perusahaan Terhadap Luas Voluntari Disclosure Laporan Keuangan Tahunan. Proceeding PESAT, Vol.2.

Wardhani, W. K., \& Samrotun, Y. C. (2020). Pengaruh Kepemilikan Institusional, Kepemilikan Manajerial, Ukuran Perusahaan dan Leverage terhadap Integritas Laporan Keuangan. Jurnal Ilmiah Universitas Batanghari Jambi, 475-481. 